\title{
MADRE SEBAGAI SIMBOL RUMAH DAN KELUARGA DALAM MADRE KARYA DEWI LESTARI
}

\author{
WAHYUNI WUMU \\ Kantor Bahasa Gorontalo \\ Jalan Dokter Zainal Umar Sidiki, Tunggulo, Tilongkabila, Bonebolango \\ wahyuniwumu@gmail.com
}

\begin{abstract}
Abstrak
Dalam berbagai bentuk karya sastra banyak ditemukan simbol-simbol atau tanda yang digunakan penciptanya untuk memberi arti yang lebih mendalam terhadap apapun itu yang menjadi objek karya sastra tersebut. Tujuan penulisan ini untuk menemukan makna yang mewakili berbagai perasaan dan harapan manusia terhadap kehidupan. Penelitian ini menggunakan metode pengumpulan data kualitatif dengan analisis data menggunakan metode deskriptif. Hasil analisis data menunjukkan bahwa di dalam cerpen Madre adonan roti yang bernama Madre menjalankan fungsi penting dalam kehidupan manusia yang terlibat dengannya, melampaui bentuknya sendiri yang hanya berupa adonan roti. Dewi Lestari dengan apik menghadirkan madre sebagai representasi berbagai harapan tentang arti rumah, keluarga, dan cinta bagi karakter-karakter dalam cerpennya.
\end{abstract}

Kata kunci: simbol, tanda, Madre

\section{Abstract}

In various forms of literary works, there are many symbols or signs used by the writer to give a deeper meaning to whatever is the object of the literary work. These symbols and signs have meanings that represent various human feelings and expectations for life. This is what this article wants to convey most. This study used qualitative methods in data collecting, and the data required to be analized by descriptive method. The results showed that a bread dough that plays an important role in the human life to whom it got connected with, beyond of its own form which is only a dough. Dewi Lestari nicely presents Madre as a representation of various expectations about the meaning of home, family, and love for all the characters in her short story.

Keywords: symbols, signs, Madre

\section{PENDAHULUAN}

Dewi Lestari dan tim menempatkan "Madre" sebagai cerita pertama sekaligus membuatnya sebagai cover kumpulan cerpen dengan judul yang sama. Pemilihan gambar roti sourdough mekar yang sudah diiris-iris menjadi unsur menarik sekaligus tanda tanya bagi pembaca sudah pasti yang akan menebak kisah di dalam buku ini. Bila diamati, judul Madre dan gambar roti sourdough sudah jelas sama sekali tidak berkaitan. Kata madre berasal dari bahasa Spanyol yang berarti ibu, mama. Sementara roti sourdough adalah sejenis roti klasik yang kini sudah jarang ditemukan seiring membanjirnya gerai-gerai fine bread waralaba yang kian menjamur di berbagai pelosok kota. Roti sourdough adalah roti yang dibuat menggunakan fermentasi ragi liar tanpa penambahan ragi instan maupun bread improver. Ragi liar ini dapat dibuat dari tepung gandum, buah-buahan bahkan sayur-sayuran 
dengan cara di fermentasi sebelum dijadikan biang sourdough.

Pada judul madre, huruf " $\mathrm{D}$ " menggunakan gambar kunci yang di balik sehingga membentuk huruf " $D$ " kecil. Lalu di sekeliling gambar roti sourdough dan tulisan madre, terdapat garis melingkar hitam yang terlihat seperti jalinan kawat (atau kabel) yang bila dilihat secara seksama, menyerupai bentuk otak manusia. Gambar cover yang dirancang sedemikian rupa tentu mengandung berbagai pesan. Madre, ditempatkan sebagai "kunci" segalanya, think tank yang akan memicu berbagai peran manusia yang memiliki hubungan dengannya, dalam hal ini yaitu Tansen, Pak Hadi, Pak Joko, Mei, Bu Dedeh dan beberapa karyawan uzur Tan de Bakker lainnya, yang bukan saja menggantungkan hidup pada kelangsungan usaha toko roti, namun juga memiliki harapan yang terbentang dan perasaan yang mendalam terhadap madre.

Setiap sesuatu pasti diciptakan untuk suatu hal tertentu atau dengan tujuan tertentu yang bermanfaat. Begitu pula dengan karya sastra, setiap karya sastra tidak sekadar diciptakan untuk hiburan semata. Tetapi, ada maksud dan tujuan tertentu. Sastra berfungsi sebagai penghibur sekaligus mengajarkan sesuatu (Wellek dan Warren, 1990:25). Karena itu sastra sering dianggap indah dan bermanfaat.

Novel atau cerpen sebagai bagian bentuk sastra merupakan jagad realita yang di dalamnya terjadi peristiwa dan perilaku yang dialami dan diperbuat oleh manusia (Siswantoro, 2005). Sebagai bagian dari karya sastra, novel atau cerpen yang muncul tak hanya digunakan sebagai hiburan, tetapi novel atau cerpen tersebut dapat juga digunakan sebagai media pendidikan. Kehadiran novel atau cerpen sebagai bagian karya sastra tak terlepas dari unsur intrinsik. Sastra adalah hasil pekerjaan seni kreatif yang objeknya adalah manusia dan kehidupannya dengan menggunakan bahasa sebagai medianya. Sebagai seni kreatif yang mengungkapkan kehidupan manusia, karya sastra tidak hanya merupakan media untuk menyampaikan ide, teori, atau sistem berpikir, tetapi juga merupakan media untuk menampung ide, teori serta sistem berpikir manusia. Oleh karena itu, sebagai karya kreatif, sastra harus mampu melahirkan suatu kreasi yang indah dan berusaha menyalurkan kebutuhan keindahan manusia. Di samping itu, sastra harus mampu menjadi wadah penyampaian ide-ide yang dipikirkan dan dirasakan oleh sastrawan tentang kehidupan umat manusia (Semi, 1993).

Kumpulan cerita Madre adalah sebuah kumpulan cerita yang ditulis oleh Dewi Lestari. Sebagai seorang penulis dan penyanyi, Dee, sapaan akrab Dewi Lestari dapat dikatakan sebagai seorang penyanyi yang sukses di bidang kepenulisan. Kumpulan cerita Madre ini menyampaikan cerita yang lebih detil dan ringkas, tidak seperti sebuah novel yang panjang. Konflik batin yang dihadirkan oleh penulis tidak berbelit-belit karena tokoh yang dihadirkan dalam cerita pun tidak terlalu banyak. Nurgiyantoro menyatakan fiksi merupakan hasil dialog, kontemplasi, dan reaksi pengarang terhadap lingkungan dan kehidupan 
(2009:3). Selanjutnya, Tarigan (1991) juga menyebutkan bahwa fiksi adalah sesuatu yang dibentuk; sesuatu yang dibuat; sesuatu yang diciptakan; sesuatu yang diimajinasikan. Contoh cerita fiksi yaitu cerpen dan novel. Beach (Tarigan, 1991:176) menyatakan bahwa mengingat batas-batasnya maka cerita pendek termasuk bentuk yang sederhana dari fiksi. Dari pengertian tersebut jelas bahwa cerpen merupakan hasil olahan ide yang didapatkan dari kehidupan nyata yang dipadukan dengan imajinasi pengarang sehingga menghasilkan cerita yang menarik dan tidak terlalu panjang.

Tokoh-tokoh yang terdapat di dalam cerpen Madre, yaitu Tansen, Pak Hadi, Mei, Bu Cory, Bu Sum, Bu Dedeh, dan Pak Joko. Tansen sebagai digambarkan sebagai pemuda yan bertanggung jawab dan pekerja keras. Tansen digambarkan sebagai sosok pria yang berkulit gelap, rambut gimbal, hidung panjang, dan berbulu mata lentik. Tansen juga diceritakan memiliki jiwa yang kuat.

Tokoh penting lain dalam cerpen ini adalah Pak Hadi. Pak Hadi digambarkan sebagai laki-laki yang berusia sekitar 80 tahun, muka keriput, kedua cuping telinga melebar, di seputar pipi terdapat vlek, bertubuh kurus, tetapi tegap. Pak Hadi digambarkan sebagai orang yang memegang teguh prinsip dan memiliki kesabaran, setia pada majikan.

Tokoh penting lain dalam cerpen ini adalah Mei yang digambarkan sebagai sosok pekerja keras yang mati-matian melakukan segalanya untuk menebus kesalahan yang pernah dilakukannya dulu. Tokoh Mei digambarkan sebagai gadis dengan latar belakang etnis Tionghoa dengan mata besar dan bulat, kulit kuning bersih, dan betis yang mungil. Mei adalah representasi wanita muda ibukota dengan kepribadian menarik dan penampilan cantik. Sewaktu ia masih kecil, Mei melakukan suatu kesalahan yang terus membebani hatinya hingga ia dewasa.

Semua tokoh dalam cerpen dalam cerpen ini memiliki latar belakang dan tujuan hidup yang berbeda. Namun secara ajaib mereka semua seakan digiring untuk memiliki takdir yang sama seiring dengan masuknya Madre dalam kehidupan mereka.

\section{TEORI}

Penelitian ini mengungkapkan simbol yang terdapat dalam cerpen Madre karya Dewi Lestari, yang diwakili dengan indah dan penuh makna oleh sebuah adonan roti yang di beri nama Madre. Sebagaimana yang dikatakan oleh Peirce bahwa penalaran manusia senantiasa dilakukan melalui tanda, demikian pula beberapa peristiwa penting dalam cerpen Madre yang bila dicermati lebih dalam merupakan tanda atau simbol yang mewakili berbagai makna peristiwa, perasaan, kenangan, dan harapan tiap-tiap karakter yang ada di dalam cerpen.

Bahasa merupakan simbol karena berdasarkan konvensi yang telah ada dalam suatu masyarakat. Selain rambu-rambu lalulintas, kode simpul kepramukaan, kode S.O.S juga merupakan simbol (Peirce dalam Zaimar 2008:6). 
Simbol muncul dalam konteks yang sangat beragam dan digunakan untuk berbagai tujuan. Dalam bahasa komunikasi sering disebut dengan lambang. Simbol atau lambang adalah sesuatu yang digunakan untuk menunjuk sesuatu yang lain berdasarkan kesepakatan kelompok orang (Wellek dan Warren 1995:239).

Menurut Tinarbuko (2012:17) simbol merupakan tanda berdasarkan konvensi, peraturan atau perjanjian yang disepakati bersama. Simbol baru dapat dipahami jika seseorang sudah mengerti arti yang telah disepakati sebelumnya. Contohnya: Garuda Pancasila bagi bangsa Indonesia adalah burung yang memiliki perlambangan yang kaya makna, namun bagi orang Eskimo misalnya, Garuda Pancasila hanya dipandang sebagai burung elang biasa.

Sebuah simbol, dari perspektif Saussure (dalam Berger 2005:23) adalah sejenis tanda yang antara penanda dan petanda seakan-akan bersifat arbitrer. Konsekuensinya hubungan kesejarahan akan berpengaruh dalam pemahamannya. Berger berpendapat (2005:23) sebuah simbol adalah segala sesuatu yang mempunyai signifikasi dan resonansi kebudayaan. Simbol tersebut memiliki kemampuan untuk mempengaruhi dan juga memiliki makna yang dalam. Sebagaimana telah ditunjukkan para penganut Saussure memandang simbol secara konvensional. Dalam mempelajari pengertian simbol dan mengasosiasikannya dengan semua jenis kejadian, pengalaman-pengalaman dan sebagainya yang sebagian besar memiliki pengaruh emosional bagi kita dan orang lain.

Hartoko dan Rahmanto (dalam Sobur 2009:157) membedakan simbol menjadi tiga, yaitu:

a. Simbol-simbol universal, berkaitan dengan arketipos, misalnya tidur sebagai lambang dari kematian.

b. Simbol kultural yang dilatarbelakangi oleh kebudayaan tertentu, misalnya keris dalam budaya Jawa.

c. Simbol individu yang biasanya dapat ditafsirkan dalam konteks keseluruhan karya pengarang.

Pradopo (2008:120) menyatakan bahwa simbol menunjukkan tidak adanya hubungan alamiah antara penanda dengan petandanya, hubungannya bersifat arbitrer. Arti tanda ditentukan oleh konvensi. Misalnya ibu adalah simbol, artinya ditentukan oleh konvensi masyarakat bahasa Indonesia. Orang Inggris menyebutnya mother, atau orang Perancis menyebutnya la mere. Jadi, dalam bahasa tanda yang paling sering digunakan adalah simbol.

Simbol (symbol) berasal dari bahasa Yunani, sym-ballem yang berarti melemparkan bersamaan sesuatu (benda, perbuatan) dikaitkan dengan suatu ide. Ada pula yang menyebutkan symbolos yang berarti tanda atau ciri untuk memberitahukan suatu hal kepada seseorang. Biasanya simbol terjadi berdasarkan metonimi, yaitu nama untuk benda lain yang berasosiasi atau menjadi atributnya dalam metafora dengan kata lain pemakaian kata atau ungkapan lain untuk obyek atau konsep lain berdasarkan 
persamaan. Semua simbol melibatkan tiga unsur yaitu simbol itu sendiri, satu rujukan atau lebih, dan hubungan antara simbol dan rujukan. Ketiga hal tersebut merupakan dasar bagi semua makna simbolik (Sobur 2009:155).

Simbol adalah tanda yang menunjukkan hubungan alamiah antara penanda dan petandanya. Hubungan diantaranya bersifat arbitrer, hubungan berdasarkan konvensi masyarakat. Dalam konsep Peirce (2009:155) simbol diartikan sebagai tanda yang mengacu pada obyek tertentu di luar tanda itu sendiri. Hubungan antara simbol sebagai penanda dengan sesuatu yang ditandakan (petanda) sifatnya konvensional.

Cassier (dalam Herusatoto 2000:9) mengemukakan bahwa manusia tidak pernah melihat, menemukan, dan mengenal dunia secara langsung tanpa melalui berbagai simbol. Kenyataan memang merupakan sekadar faktafakta, tetapi ia mempunyai makna yang bersifat kejiwaan. Di dalam simbol terkandung unsur pembesaran dan perluasan pandangan. Jadi manusia membuat jarak antara apa yang nampak pada alam sekelilingnya.

Masih dalam Herusatoto (2000:10) dinyatakan bahwa simbol merupakan pembabaran langsung pada penghayatan terhadap jiwa dan raga yang mempunyai bentuk serta watak dengan unsurnya masing-masing dan sebagai wujud pembabaran batin seseorang yang dapat berupa hasil karya seni. Kebudayaan manusia sangat erat hubungannya dengan simbol karena itulah manusia disebut dengan makhluk bersimbol. Dengan demikian terdapat makna dalam simbol. Makna tersebut tersimpan dalam bahasa dan untuk mengetahuinya harus melalui proses analisis serta pembedahan susunan bahasa dengan pemahaman yang optimal.

Pierce (dalam Santosa 1993:11) mengemukakan simbol adalah sesuatu yang melaksanakan fungsi sebagai penanda yang oleh kaidah secara konvensi telah lazim digunakan dalam masyarakat. Pada simbol ditampilkan hubungan antara penanda dan petanda dalam sifatnya yang arbitrer. Tanda yang berubah menjadi simbol dengan sendirinya akan dibubuhi sifat-sifat kultural, situasional, dan kondisional. Oleh sebab itu, bahasa sebenarnya merupakan prestasi kemanusiaan yang besar mengenai penanda yang bersifat arbitrer.

Simbol merupakan tanda yang maknanya tersimpan dalam kesadaran batin masyarakat pemakainya sesuai dengan konvensi yang dipahami bersama. Sementara nilai dalam sistem tanda yang secara tersirat mengandung wawasan yang hidup dalam suatu masyarakat, baik secara individual maupun kelompok disebut ideologi, sedangkan keberadaan tanda sebagai ikon, indeks, simbol beserta nilai ideologis bersifat abstrak. Ikon, indeks, dan simbol secara serempak dapat diemban sebuah tanda yang sama. Dapat dikatakan juga bahwa simbol adalah tanda yang menunjukkan tidak ada hubungan alamiah antara penanda dan petandanya, hubungannya bersifat arbitrer. Dalam bahasa Indonesia simbol pada umumnya disamakan dengan lambang. Dalam sastra, sistem simbol yang terpenting adalah bahasa 
(Ratna 2004:115). Simbol dapat dianalisis melalui suku kata, kata, kalimat, alinea, bab, dan seterusnya bahkan juga melalui tanda baca dan huruf sebagaimana ditemukan dalam analisis gaya bahasa.

Simbol merupakan pembabaran langsung yang bertumpu pada penghayatan terhadap jiwa dan raga yang mempunyai bentuk serta watak dengan unsurnya masing-masing dan sebagai wujud pembabaran batin seseorang yang dapat berupa hasil karya seni. Kebudayaan manusia sangat erat hubungannya dengan simbol, manusia disebut makhluk bersimbol (Herusatoto 2000:10). Dengan demikian terdapat makna dalam simbol dan makna tersebut tersimpan bahasa dan hanya dapat diketahui melalui proses analisis dan membedah susunan bahasa dengan pemahaman optimal.

Berbicara mengenai simbol tentu tidak bisa lepas dari pembahasan ilmu semiotik. Semiotik berasal dari bahasa Yunani Semeon yang berarti tanda. Hartoko dalam Taum, (1997: 41) mengatakan bahwa semotik adalah ilmu tentang tanda-tanda, sistem-sistem tanda, dan proses suatu tanda diartikan. Tanda itu sendiri diartikan sebagai sesuatu yang bersifat representatif, mewakili sesuatu yang lain berdasarkan konvensi tertentu. Konvensi yang memungkinkan suatu objek, peristiwa, atau gejala kebudayaan yang menjadi tanda itu disebut juga sebagai kode sosial. Tanda-tanda itu mempunyai arti dan makna, yang ditentukan oleh konvensinya, karya sastra merupakan struktur tanda-tanda yang bermakna. Karya sastra merupakan karya yang bermedium bahasa. Bahasa sebagai bahan sastra merupakan sistem tanda yang mempunyai arti. Sebagai bahan sastra, bahasa disesuaikan dengan konvensi sastra, konvensi arti sastra yaitu makna (significanse).

Semiotik berasal dari bahasa Yunani semeion yang berarti tanda atau sign. Tanda tersebut menyampaikan suatu informasi sehingga bersifat komunikatif, serta menggantikan suatu yang lain (stand for something else)yang dapat dipikirkan atau dibayangkan (Broadbent, 1980). A. Teew (1984: 6) mendefinisikan semiotik adalah tanda sebagai tindak komunikasi dan kemudian disempurnakan menjadi model sastra yang mempertanggungjawabkan semua faktor dan aspek hakiki untuk pemahaman gejala susastra sebagai alat komunikasi yang khas di dalam masyarakat manapun.

Semiotik yang sering disebut dengan istilah semiologi adalah ilmu yang mengkaji secara sistematis tentang tanda- tanda, lambang-lambang, proses penciptaan yang menyangkut karya sastra sebagai suatu sosok yang memiliki sistim sendiri (Semi, 1993:86).

Pendekatan semiotik analisisnya tidak terbatas pada karya sastra itu sendiri, juga berhubungan dengan hal-hal yang berada di luar karya sastra yaitu kode budaya, seperti masalah sosial budaya dan sistim tata nilai yang mewarnai karya sastra. Hal ini berarti, bahwa kajian semiotik juga menyangkut aspek ekstrinsik dan intrinsik karya satra.

Teori kritik sastra semiotik lebih mementingkan pada makna dalam suatu karya 
sastra. Menurut Luxemburg dkk (diterjemahkan Hartoko 1982: 44) semiotik berasal dari bahasa Yunani, yaitu semeion artinya tanda, jadi dalam dunia sastra semiotik adalah analisis karya sastra yang mengacu pada sistem tanda yang ada di dalam karya sastra. Menurut Berger (2013: 22) semiotika adalah ilmu tentang tanda, tanda yang dimaksudkan adalah tanda apa saja.

Semiotik adalah ilmu tentang tandatanda. Ilmu ini menganggap bahwa fenomena sosial atau masyarakat dan kebudayaan merupakan tanda-tanda. Preminger (dalam Pradopo 1995:119) dalam sastra sebagai sebuah penggunaan bahasa yang bergantung pada konvensi-konvensi tambahan dan meneliti ciriciri yang menyebabkan berbagai macam cara wacana mempunyai makna. Menurut Roland Barthes, semiotika adalah suatu ilmu atau metode analisis untuk mengkaji tanda. Semiotika Barthes merupakan pengembangan dari semiotika Saussure dengan menyelidiki hubungan antara tanda (signifier) dan petanda (signified) pada sebuah tanda (sign). Hubungan penanda dan petanda bukanlah kesamaan tapi ekuivalen. Bukannya yang kemudian membawa pada yang lain tetapi hubunganlah yang menyatukan keduanya (Kurniawan, 2001:22).

Hoed (dalam Nurgiyantoro 1995:40) berpendapat semiotik adalah ilmu atau metode analisis untuk mengkaji tanda. Tanda adalah sesuatu yang mewakili sesuatu yang lain yang dapat berupa pengalaman, pikiran, perasaan, gagasan dan lain-lain. Jadi, yang dapat menjadi tanda sebenarnya bukan hanya bahasa saja, melainkan berbagai hal yang melingkupi kehidupan ini, walau harus diakui bahwa bahasa adalah sistem tanda yang paling lengkap dan sempurna. Semiotik merupakan ilmu yang secara sistematik mempelajari tanda-tanda dan lambang-lambang atau dalam bahasa Yunani berasal dari kata semeion, sistem-sistem lambang dan proses-proses perlambangan.

Semiotika atau semiologi (Santoso 1993:2), keduanya memiliki pengertian yang sama yaitu ilmu tentang tanda. Semiotika maupun semiologi berasal dari bahasa Yunani yaitu semeion yang berarti tanda. Teeuw (dalam Santoso 1993:3) memberi batasan semiotika adalah tanda sebagai tindak komunikasi. Semiotika adalah model sastra yang mempertanggungjawabkan semua faktor dan aspek hakiki untuk pemahaman gejala susastra sebagai alat komunikasi yang khas di dalam masyarakat.

Dick Hartoko (dalam Santoso 1993:3) memberi batasan semiotika adalah bagaimana karya itu ditafsirkan oleh para pengamat dan masyarakat lewat tanda-tanda atau lambanglambang. Luxemburg (dalam Santoso 1993:3) lewat pengindonesiaan Dick Hartoko menyatakan bahwa semiotika adalah ilmu yang secara sistematis mempelajari tanda-tanda dan lambang-lambang, sistem-sistemnya dan proses perlambangan. Semiotika dapat dijadikan sebagia ilmu yang mengkaji tentang kehidupan tanda dalam maknanya yang luas di dalam masyarakat, baik yang lugas (literal) maupun yang kias (figurative) baik menggunakan bahasa maupun non bahasa. 
Semiotik atau semiologi berarti studi sistematis atas tanda (Eagleton 2006:144). Semiotik menamai sebuah bidang tertentu yaitu studi sistem yang biasanya dianggap sebagai tanda. Zaimar (dalam Nurgiyantoro 1994:11) mengemukakan kenyataan bahwa bahasa merupakan sebuah sistem, mengandung arti bahwa bahasa terdiri dari sejumlah unsur, dan tiap unsur saling berhubungan secara teratur dan berfungsi sesuai dengan kaidah, sehingga bahasa dapat dipakai untuk berkomunikasi.

Di dalam wawasan semiotika, wujud konkrit perlambangan itu disebut signal (tanda). Sebagai pewujud karya sastra tanda yang satu dengan yang lain membentuk hubungan secara sistematis, sebab itu signal dapat pula dinyatakan sebagai sistem tanda (Jabrohim 1994:119). Jadi, dari uraian pengertian yang dijelaskan semiotik adalah segala sesuatu tentang tanda. Sebagai ilmu yang mempelajari tanda, semiotik mempunyai lapangan semiotik. Hal penting dalam semiotik adalah sistem tanda. Tanda adalah sesuatu yang mewakili sesuatu yang yain yang dapat beruapa pengalaman, perasaan, pikiran dan lain-lain.

Semiotika menurut Berger (2012:11) memiliki dua tokoh, yakni Ferdinand de Saussure dan Charles Sander Peirce. Kedua tokoh tersebut mengembangkan ilmu semiotika secara terpisah dan tidak saling mengenal satu sama lain. Saussure di Eropa sedangkan Peirce di Amerika Serikat. Latar belakang Saussure adalah linguistik dan Peirce filsafat.

Pada dasarnya istilah semiologi dan semiotika mengandung pengertian yang persis sama, walaupun penggunaan kedua istilah tersebut biasanya menunjukkan pemikiran pemakainya, mereka yang bergabung dengan Peirce menggunakan kata semiotika, dan mereka yang bergabung dengan Sausure menggunakan kata semiologi. Namun yang terakhir, semakin jarang dipakai jika dibandingkan dengan yang pertama

Semiologi menurut Saussure (dalam Berger, 2005:3) studi sistematis suatu tanda. Pendapat ini didasarkan pada anggapan bahwa selama perbuatan dan tingkah laku manusia membawa makna atau berfungsi sebagai tanda, dibelakangnya ada sistem pembedaan dan konvensi yang memungkinkan makna itu. Di mana ada tanda, di sana ada sistem.

\section{Bagi Peirce (dalam Zaimar, 2008:3)} yang merupakan ahli filsafat dan logika, penalaran manusia senantiasa dilakukan melalui tanda. Artinya, manusia hanya dapat bernalar melalui tanda. Dalam pemikirannya, logika sama halnya dengan semiotika dan dapat diterapkan pada segala macam tanda. Menurut Luxemburg, Bal, dan Weststeijn (1989:44) semiotik adalah ilmu yang secara sistematik mempelajari tanda-tanda dan lambang-lambang, sistem-sistem lambang dan proses-proses perlambangan. Dengan demikian bahasa pun dapat dinamakan semiotik.

Premingher (dalam Jabrohim, 2001: 98) mengemukakan bahwa studi sastra yang bersifat semiotik adalah usaha untuk menganalisis karya sastra sebagai suatu sistem tanda-tanda dan menentukan konvensi-konvensi apa yang memungkinkan karya sastra mempunyai makna. 
Dengan melihat variasi-variasi di dalam struktur karya sastra atau hubungan dalam antar unsurunsurnya, akan dihasilkan bermacam-macam makna. Dalam puisi (sajak) satuan-satuan berfungsi itu di antaranya adalah satuan bunyi, kata, diksi dan bahasa kiasan, dan kalimat. Di samping itu di antara konvensi tambahan adalah persajakan, enjambement, tipografi, pembaitan, dan konvensi-konvensi lain yang memberi makna dalam sastra.

Pandangan lain diungkapkan oleh Hoed (dalam Nurgiyantoro, 1994:40) bahwa semiotik merupakan metode analisis untuk mengkaji tanda yang merupakan sesuatu yang mewakili sesuatu yang lain yang berupa pengalaman, pikiran, perasaan, gagasan, dan lain-lain. Jadi yang menjadi tanda sebenarnya bukan hanya bahasa saja, melainkan berbagai hal yang melingkupi kehidupan ini, meski harus diakui bahwa bahasa merupakan sistem tanda yang paling lengkap dan sempurna. Tanda-tanda itu dapat berupa gerakan anggota badan, gerakan mata, mulut, bentuk tulisan, warna, bentuk, pakaian, karya seni, dan lain-lain yang berada di sekitar kehidupan. Dengan demikian semiotik bersifat multidisiplin.

Karya sastra merupakan struktur yang kompleks sehingga untuk memahami sebuah karya sastra diperlukan analisis. Analisis tersebut merupakan usaha secara sadar untuk menangkap dan memberi muatan makna kepada teks sastra yang memuat berbagai sistem tanda. Seperti yang dikemukakan oleh Saussure bahwa bahasa merupakan sebuah sistem tanda, dan sebagai suatu tanda bahasa mewakili sesuatu yang lain yang disebut makna (Nurgiyantoro, 2002: 39). Bahasa tak lain adalah media dalam karya sastra. Karena itu karya sastra merupakan sebuah struktur ketandaan yang bermakna (Kaswadi, 2006: 123). Semiotik sebagai ilmu berfungsi untuk mengungkapkan secara keseluruhan tanda dalam kehidupan manusia, baik tanda verbal maupun nonverbal. Sebagai pengetahuan praktis, pemahaman terhadap kebenaran tanda-tanda, khususnya yang dialami dalam kehidupan sehari-hari berfungsi untuk meningkatkan kualitas kehidupan melalui efektivitas dan efisiensi energi yang harus dikeluarkan (Ratna, 2004:105)

Dalam pengertian yang lebih luas, teori semiotika berarti studi sistematis mengenai produksi dan interpretasi tanda, bagaimana cara kerjanya dan apa manfaatnya terhadap kehidupan manusia. Manusia adalah makhluk tanda, dalam kehidupannya dipenuhi dengan tanda, karena melalui perantara tanda-tanda manusia dapat berkomunikasi dengan sesamanya. Sekaligus mengadakan pemahaman yang lebih baik terhadap dunia, dengan begitu manusia dapat disebut homo semioticus.

Menurut Nurgiyantoro (2002:40), semiotik adalah ilmu atau metode analisis untuk mengkaji tanda. Teori semiotik dapat dibedakan menjadi dua jenis, yaitu semiotika komunikasi yang menekankan diri teori produksi tanda dan semiotika signifikasi yang menekankan pemahaman atau pemberian makna suatu tanda. Pengkajian sastra menggunakan teori semiotik merupakan analisis karya sastra yang menjadikan karya sastra itu sebagai objek tanda- 
tanda yang memungkinkan karya sastra itu memiliki arti tertentu. Pokok pemikiran dari semiotik adalah tanda. Tanda memiliki dua aspek, yaitu aspek petanda (signifier) dan aspek penanda (signified). Menurut Pradopo (2013: 119) semiotik adalah ilmu tanda, yang dianggap tanda merupakan fenomena sosial atau masyarakat dan juga budaya. Berdasarkan pemaparan di atas semiotik adalah ilmu yang mempelajari tentang tanda yang ada di dalam karya sastra. Analisis menggunakan teori semiotik tidak bisa dijauhkan dengan teori struktural, karena pada setiap sisi struktur dari suatu karya sastra akan memiliki tanda-tanda tertentu di dalamnya.

Susanne Langer dalam (Littlejhon, 2009: 66-67) membedakan antara tanda dan simbol. Tanda berkaitan erat dengan objek yang ditandai; misalnya mendung tandanya hujan, tertawa tandanya bahagia. Sedangkan simbol tidak mewakili objek tetapi merupakan kendaraan atau sarana pengkonsepsian objekobjek. Sebuah simbol adalah sebuah intrumen pemikiran. Langer melihat meaning sebagai hubungan kompleks antar simbol, objek dan individu. Jika minimal tidak terdapat sesuatu yang dimaknai dan pemikiran seseorang yang memaknainya, maka tidak terdapat makna yang sempurna. Oleh karena itu terdapat makna logika dan makna psikologis. Makna logika adalah hubungan antara simbol dan objek (referent), sedangkan makna psikoligis adalah hubungan antara simbol dan seseorang.

Dalam semiotika, penerima dan pembaca, dipandang memainkan peran yang lebih aktif dibandingkan dalam kebanyakan model proses. Ferdinand de saussre, hanya benar-benar menaruh perhatian pada simbol, karena kata-kata adalah simbol. Namun para pengikutnya mengakui bahwa bentuk fisik dari tanda yang oleh Saussure dinamakan penanda (signifier), konsep mental yang terkait dengannya petanda (signified) dapat dikaitkan dengan cara ikonik atau atbitrer. Signifier (penanda) adalah bunyi atau coretan bermakna, sedangkan signified adalah gambar mental atau konsep sesuatu dari signifier (penanda). Hubungan antara keberadaan fisik tanda atau konsep mental tanda tersebut dinamakan signification. Dengan kata lain signification ada upaya memberi makna terhadap dunia (Fiske, 2004:66).

Signifier dan signified adalah produk kultural. Hubungan di antara keduanya bersifat abriter (manasuka) dan hanya berdasarkan konvensi, kesepakatan atau peraturan dan kultural pemakai bahasa tersebut. Hubungan antara signifier dan signified tidak bisa dijelaskan dengan nalar apapun, baik pilihan bunyi -bunyian maupun pilahan untuk mengkaitkan rangkaian bunyi tersebut dengan benda atau konsep yang dimaksud, karena hubungan yang terjadi antara signifier dan signified bersifat arbiter, maka signifier harus dipelajari, yang berarti ada struktural yang pasti atau kode yang membantu menafsirkan makna (Sobur, 2001:126).

Semiotika dapat meneliti berbagai teks. Teks disini adalah pengertian dalam arti luas. Teks tidak hanya dibatasi pada aspek tulisan 
atau linguistik saja. Semiotik dapat meneliti teks dimana tanda-tanda terkodefikasi dalam sebuah sistem. Dengan demikian semiotik dapat meneliti bermacam-macam teks, seperti berita, iklan, drama dan sebagainya. Roland Barthes yang juga menjadikan semiotika sebagai pendekatan utama ilmu budaya, ia juga menjelaskan maksud dari semiotika adalah untuk menerima semua sistem tanda, apapun hakekatnya dan batasnya, baik gambar, isyarat, suara musik, objek dan semua hal-hal tersebut, yang membentuk kebiasaan atau hal lain, yang bukan berupa bahasa, paling tidak adalah suatu sistem signikasi, yaitu adanya hubungan antara signifier dan signified untuk memberikan makna.

Pendekatan semiotik memberi pandangan bahwa tanda-tanda atau kode-kode sekecil apapun yang terdapat dalam karya sastra penting untuk diperhatikan, karena ia ikut membentuk sistem dan keseluruhan tersebut. Teeuw (dalam Pradopo, 2003:223) juga mengungkapkan bahwa karya sastra tidak lahir dalam situasi kekosongan budaya. Hal ini berarti bahwa karya sastra sesungguhnya merupakan konvensi masyarakat.

Dalam telaah cerita pendek, metode semiotik digunakan agar mendapat kemudahan dalam pemahaman seseorang dalam mempelajari sebuah cerita pendek. Metode semiotik digunakan sebagai pendekatan untuk menganalisis teks cerita pendek dengan asumsi bahwa cerpen itu dikomunikasikan melalui tanda-tanda. Cerita pendek yang tersusun tidak membawa makna pesan tunggal. Cerita pendek biasanya mempunyai ideologi dominan yang tercipta melalui tanda tersebut. Hal ini menunjukkan bahwa teks cerpen mempunyai kepentingan-kepentingan tertentu.

Pada bahasa Indonesia simbol umumnya disamakan dengan lambang. Dalam sastra, sistem simbol yang terpenting adalah bahasa. Leach (dalam Ratna, 2011:115) menyatakan bahwa suatu gejala disebut simbol tergantung dari penggunanya. Tanda dalam sastra sangat banyak. Simbol dapat dianalisis melalui suku kata, kata, kalimat, alinea, bab bahkan juga melalui tanda baca dan huruf, sebagaimana ditemukan dalam analisis gaya bahasa. Simbol ditandai oleh dua ciri yaitu, a) antara penanda dan petanda tidak ada hubungan intrinsik sebelumnya; b) termasuk ke dalam konteks kultural yang sama (Ratna, 2011:116). Sistem simbol juga dapat dianalisis dengan memanfaatkan fokalisasi (Zoest dalam Ratna, 2011:116).

Analisis semiotika yang menjadi dasar tulisan ini memberikan jalan bagi penulis untuk mempresentasikan pesan moral yang terkandung di dalam cerpen ke dalam rangakaian kata-kata atau kalimat. Dalam membentuk kalimat yang digunakan harus memiliki sistem agar bermakna. Sistem inilah yang disebut representasi. Representasi merupakan pengertian yang berlaku di dalam masyarakat mengenai berbagi macam fenomena nasional.

Berdasarkan uraian dan pendapat para ahli di atas maka dapat disimpulkan bahwa semiotik adalah ilmu yang mengkaji secara sistematis 
tentang tanda, lambang ataupun simbol yang menyangkut pada sebuah karya sastra. Hal tersebut bertitik tolak dari asumsi bahwa karya sastra, memiliki sistim tanda/lambang bahasa yang bermakna dengan media bahasa yang estetik. Berdasarkan semiotik bahasa merupakan salah satu tanda atau lambang dan lambanglambang bahasa itu berupa kata, kalimat, dan teks. Sistim tanda tersebut mempunyai makna atau pengertian tertentu berdasarkan hasil interpretasi si penerima tanda atau lambang bahasa bahasa tersebut. Karena sistim lambang atau tanda dalma karya sastra memiliki banyak intrepretasi. Dalam kajian semiotik analisisnya tidak terbatas pada pemakaian bahasa dan sistim tanda/lambang yang terdapat dalam karya sastra saja tetapi juga berhubungan dengan hal-hal yang berada di luar karya sastra tersebut. Yaitu kode seperti masalah sosial budaya dan sistim tata nilai yang mewarnai karya sastra tersebut. Oleh karena itu masalah yang hendak disoroti dalam kajian semiotik adalah keunikan, kekhasan suatu karya sastra sehingga penelaah harus jeli melihat lambang-lambang dan kode sastra yang membentuk sistim dari keseluruhan isi karya sastra itu sendiri.

\section{METODE}

Penelitian ini menggunakan metode kualitatif, karena datanya berbentuk deskriptif yang berupa kata-kata tertulis (bahasa tulis). Jadi pada karya sastra (novel) yang akan diteliti khusus membahas simbol melalui kajian semiotik, karena karya sastra menggunakan bahasa sebagai mediumnya akan kaya dengan simbol-simbol yang terdapat di dalamnya. Dan dalam sastra sistem simbol yang terpenting adalah bahasa.

Menurut Bogdan dan Taylor (dalam Ismawati 2011:10), mendefinisikan penelitian kualitatif sebagai prosedur penelitian yang data berbentuk deskriptif, yaitu berupa kata-kata tertulis atau lisan dari orang-orang dan pelaku yang dapat diamati, pendekatan ini diarahkan pada latar individu secara utuh, jadi tidak boleh mengisolasikan, individu atau organisasi ke dalam variabel atau hipotesis, akan tetapi perlu memandangnya sebagai suatu bagian dari keutuhan. Berdasarkan pendapat para ahli di atas, maka jenis penelitian ini adalah deskriptif dengan metode kualitatif, serta menggunakan pendekatan semiotik.

Cerpen ialah cerita atau narasi (bukan analisis argumentasi) yang fiktif (tidak benarbenar telah terjadi tetapi dapat terjadi di mana saja dan kapan saja) serta relatif pendek (Sumardio dan Saini, 1991:37). Sementara pengertian cerpen menurut Sayuti (1992:6) ialah prosa fiksi yang selesai di baca dalam sekali duduk dan ceritanya cukup membangkitkan efek tertentu dalam diri pembaca. Sedangkan menurut Najid (2003: 18) cerpen ialah prosa fiksi yang relatif pendek. Edgar Allan Poe (Nurgiyantoro, 20017: 10) menyatakan bahwa cerpen ialah sebuha cerita yang di baca dalam sekali duduk, kira-kira berkisar antara setengah sampai satu jam.

Karya sastra merupakan dunia yang otonom, yang tidak terikat kepada dunia nyata dan tidak menunjuk pada dunia nyata, kecuali melalui 
makna unsur bahasa yang dipakai di dalamnya (Teeuw 1983:21). Karya sastra bukan hanya sebagai sarana komunikasi yang biasa, dan mempunyai banyak segi aneh dan luar biasa kalau dibandingkan dengan tindak komunikasi yang lain, tetapi pemahaman gejala ini yang sesuai dan tepat tidak mungkin tanpa memperhatikan aspek komunikatif atau dengan istilah lain karya sastra dapat dipandang sebagai gejala semiotik (Teeuw 1984:43). Di dalam karya sastra terdapat aturan-aturan, sistemsistem dan konvensi yang dapat memungkinkan tanda-tanda tersebut mempunyai arti.

Dalam penelitian ini difokuskan pada karya sastra berjenis cerita pendek. Cerita pendek termasuk salah satu genre sastra yang tergolong jenis prosa. Cerita pendek adalah sebuah cerita yang selesai dibaca dalam sekali duduk, kira-kira berkisar antara setengah sampai dua jam suatu hal yang kiranya tak mungkin dilakukan untuk sebuah novel (Jassin dalam Nurgiyantoro, 1995: 10). Menurut Shipley (dalam Tarigan, 1991: 194) mengemukakan nilai-nilai dalam sastra meliputi lima macam, yaitu (1) nilai hedonik, nilai yang memberi kesenangan secara langsung, (2) nilai artistik, nilai yang memanifestasikan keterampilan seseorang, (3) nilai kultural, nilai yang mengandung hubungan yang mendalam dengan masyarakat, (4) nilai etis religius, jika di dalamnya terkandung ajaran moral, etika, dan agama, dan (5) nilai praktis, jika di dalamnya terkandung hal-hal yang dapat dilaksanakan dalam kehidupan sehari-hari.

\section{HASIL DAN PEMBAHASAN}

Kisah ini diawali dengan kisah pertemuan Tansen dengan pengacara kakeknya di sebuah pekuburan. Melalui pertemuan yang tidak terencana itu Tansen menemukan dirinya adalah pewaris sebuah toko roti tua yang sudah bertahun-tahun mati suri.

"Apa rasanya jika sejarah kita berubah dalam sehari? Darah saya mendadak seperempat Tionghoa, nenek saya seorang penjual roti, dan dia, bersama kakek yang tidak saya kenal, mewariskan anggota keluarga baru yang tidak pernah saya tahu: "Madre"

Pertemuan awal Tansen dengan akar keturunannya yang mengejutkan selanjutnya akan diikuti oleh berbagai peristiwa menarik yang menarik Tansen semakin dalam menuju Madre. Beberapa temuan dalam cerpen ini juga menunjukkan bahwa Madre menjadi pusat kehidupan bagi karakter utama dan pendukung kisah ini. Signifikansi Madre bagi masingmasing karakter dapat dilihat dalam beberapa kutipan penting yang terangkum di bawah ini.

\section{a. Madre adalah sesuatu yang hidup, ia harus dirawat dan diperlakukan dengan baik, selayaknya manusia.}

"Madre adalah adonan biang. Hasil perkawinan antara air, tepung, dan fungi bernama Saccharomyses exiguus. Lakhsmi, nenekku, mengulturkannya sendiri. Ia bereksperimen dengan banyak bahan, dari kulit buah sampai tapai, hingga ia menemukan kultur yang menghasilkan biang dengan cita rasa yang paling pas. Melalui ulenan tangannya, Madre lahir pada tahun 1041. Bahkan, sebelum Tan de Bakker." (Madre, hal. 15) 
"Pak Hadi menghela napas. "Pagi-pagi kami akan kumpul di sini," Ucapnya pelan, "Pamit pada Madre."

"Setelah semua adonan roti beres, Pak Hadi memanggilku, "Tansen, ayo kamu yang kasih makan Madre," ia menyodorkan stoples kaca itu, "ini hari penting buat kalian berdua."

"Entah kapan aku akan terbiasa dengan cara mereka yang memperlakukan Madre dengan sangat manusiawi. Aku masih merasa lucu dikerubuti mereka uang saksama mengamatiku mengadukkan tepung dan air ke dalam Madre, seolah-olah adonan itu akan menggeliat kesenangan bagai kucing yang disayang-sayang majikan. Dan, setelah stoples-stoples berisi Madre disusun lagi di kulkas, sebelum menutup pintunya, $\mathrm{Bu}$ Cory sempat-sempatnya berkata, "Selamat istirahat, Madre." (Madre, hal. 46)

Rasa terima kasih dan penghargaan yang mendalam kepada Madre juga ditunjukkan dari cara Pak Hadi memperlakukan sebuah adonan roti dengan begitu mulia. Hal ini ditujukkan oleh Dewi Lestari pada kutipan,

"Karyawan di sini cuma lima orang. Bisnis menyusut terus. Lama-lama kami kerja ndak digaji. Akhirnya, nyerah juga dia. Ndak tega sama kami," Pak Hadi tersenyum kecut. "Yang penting, Madre jangan mati. Itu saja yang kami jaga." (Madre, hal. 8)

Begitu pula dalam tulisan lainnya, Dewi Lestari mengatakan,

"Kalau dirawat dengan benar, banyak hal di dunia ini yang makin tua makin berharga. Makin hidup dan malah makin enak" (hal. 20)
Kalimat menarik lain yang dituliskan oleh Dewi Lestari ini nampaknya perlu dicermati oleh tukang roti atau ahli pembuat roti yang ingin hasil karyanya fenomenal,

"Adonan biang yang aktif dan sehat adalah kunci penting dalam membuat roti. Lebih baik bersabar dan menunggu sampai fungi dan bakteri pada adonan biang dalam kondisi betul-betul siap tempur" (hal. 39).

\section{b. Hubungan Madre dan Tansen yang sangat unik mewarnai seluruh cerpen ini dan menjadi awal cerita.}

Diawali dengan pertemuan awal yang mengejutkan, Tansen belum menyadari hidupnya sebentar lagi akan berubah. Hal ini dapat diamati pada beberapa kutipan berikut:

"Awan hitam yang menggantung sejak dini hari akhirnya tumpah menjadi hujan lebat. Tepat saat aku tiba di pemakaman orang yang tak kukenal. Siapa dia? Itu pertanyaanku pertama. Kenapa aku? Itu pertanyaanku berikutnya. Keduanya akan terjawab pagi ini." (Madre, hal. 1)

"Seorang remaja keluar dari balik pepohonan Kamboja. Sigap memayungiku dengan ekspresi muka habis-ini-bayar-saya-goceng. Dia lalu menyapa, "Masih keluarga, Om?"

"Bukan. Keluarga? Kenal pun tidak. (Madre, hal. 1)

"Keganjilan ini pasti sebegitu mencoloknya. Di tengah TPU etnis Tionghoa, muncul seorang pria berkulit gelap, rambut gimbal, kaus tanpa lengan, jins sobek-sobek. Sendirian." (Madre, hal. 1)

"Kubaca nisan itu: "Tan Sie Gie." Wafat pada usia 93 tahun. Dia telah hidup selama itu, mencantumkan namaku sebagai ahli warisnya, dan tak secuilpun aku mengetahui 
keberadaannya. Siapa kamu? Kenapa aku?" (Madre, hal. 2)

Madre pulalah, yang secara tidak sengaja, mengenalkan Tansen pada sejarah keluarganya yang panjang. Hal ini dapat dilihat pada kisah yang diceritakan Pak Hadi kepada Tansen:

"Dibawa langsung dari Lahore tahun 1920-an, nenekkku tumbuh besar di Indonesia. Nenek menikah dengan orang Tasikmalaya. Ibuku, yang tinggal separuh India, kembali mengencerkan darah Indianya dengan menikahi orang Manado. Jadilah aku. Tansen Roy Wuisan. Kulitku menggelap lebih karena jejak matahari. Nama "Tansen", hidung panjang, dan mata besar berbulu lentik, adalah jejak India yang tersisa padaku". (Madre, hal.3)

Kejutan demi kejutan yang menghambur dalam kehidupan Tansen begitu ia berkenalan dengan Madre menimbulkan berbagai konflik tersendiri dalam diri Tansen. Seakan ingin percaya, namun di lain waktu sesuatu dalam dirinya memberontak. Hal ini dapa dilihat pada kutipan dari cerpen yang merupakan curhatan Tansen di blog pribadinya.

"Hari ini aku bercerita tentang Madre. Pertalian kami. Betapa lucunya berfamili dengan adonan roti. 'Apa rasanya sejarah hidup kita berubah dalam sehari? Kayak tahutahu kecemplung di pasir isap. Makin dalam makin sesak. Hidup saya hari kemarin lebih sederhana . Hari ini hidup saya sangat kompleks. Darah saya mendadak seperempat Tionghoa, nenek saya ternyata tukang bikin roti, dan dia, bersama kakekyang tidak saya kenal, mewariskan anggota keluarga yang tidak pernah saya tahu. (Madre, halaman 18)

Madre pula yang membawa Tansen pada warisan berharga yang ditinggalkan keluarganya, dalam bentuk sebuah toko roti.

"Tempat itu adalah bekas toko tua tanpa plang d daerah Jakarta tua. Ruko kuno dua lantai yang tak terurus; cat mengelupas, tembok kehitaman oleh lembab dan jamur, plafon menganga di sana sini, kayukayu melunak oleh rayap dan air hujan. Aku tidak yakin tempat ini dihuni. Tak ada tanda-tanda kehidupan selain gerak gerik labalaba yang bersarang dimana-mana." (Madre, hal 5)

Perkenalan Tansen dengan Madre juga menyebabkannya harus berurusan dengan orang-orang, yang dahulunya mengurusi Madre. Diantara orang-orang itu adalah Pak Hadi, lelaki tua yang ditugasi kakek Tansen untuk menjaga toko rotinya sampai keturunan Tan de Bakker yang asli akan muncul. Hal ini terlihat pada kutipan-kutipan berikut:

"Pintu besar di depanku membuka. Laki-laki Tionghoa tua berbaju olahraga menayambutku. Usianya mungkin sudah 80 -an, terbaca dari keriput mukanya yang sudah menyerupai lipatan, taburan flek di seputar pipinya, dan kedua cuping telinga yang melebar. Meski bola matanya mulai kelabu, sorot matanya tetap tajam. Tubuhnya kecil ramping dan posturnya tegap. Anehnya, ia melihatku dengan muka bosan seolah kami sudah bertemu ratusan kali, atau sudah ratusan hari dia menungguku. "Masuk", katanya pendek". (Madre, hal. 6)

"Dari cerita Pak Hadi, akhirnya aku tahu bahwa tempat itu memang toko 
roti yang mati suri. Sudah lima tahun tak beroperasi. "Tan de Bakker" adalah nama aslinya, berdiri 1943 . Tahun 60-an berubah nama menjadi Toko Roti Tan. Seiring bermunculannya bakery-bakery modern, Toko Roti Tan tenggelam pelan-pelan”. (Madre, hal. 7)

Konflik dalam bathin Tansen dikupas secara apik dalam cerita ini. Lika-liku perjalanan kegelisahan Tansen hingga akhirnya Madre hampir di jual ke tangan Mei, namun niat itu urung dilakukan Tansen.

Sejak awal kisah ini dimulai, Madre-lah yang menjadi penggerak hati Tansen, yang menyebabkan garis hidupnya berubah drastis, dari seorang manusia bebas yang hidup berdasarkan kemauannya sendiri, menjadi lakilaki mandiri yang memperhitungkan segala hal. Pada kutipan-kutipan di bawah ini dapat di cermati hal-hal tersebut.

"Seolah membaca muka laparku, Pak Hadi mengiriskan roti lagi. "Kerjamu apa di Bali?" ia bertanya. "Macammacam. Guide, ngajar surfing, desainer lepasan, penulis kadangkadang...." "Oh serabutan.” Dengan datar Pak Hadi menyimpulkan." (Madre, hal. 17)

"Meski kurang enak didengar, ucapan Pak Hadi sore tadi ada benarnya. Dalam kasusku, "serabutan" adalah gaya hidup. Menclok dari satu pekerjaan ke pekerjaan lain, satu tempat ke tempat lain, tidak ingin terikat. Aku selalu punya masalah dengan rutinitas. Mungkin aku belajar dari ayahku, atau mungkin aku justru berontak atas ketidakjelasannya. Tidak tahu pasti." (Madre, hal. 19)

“Apa rasanya sejarah hidup kita berubah dalam sehari? Kayak tahu- tahu kecemplung di pasir isap. Makin dalam makin sesak. Hidup saya hari kemarin lebih sederhana. Hari ini hidup saya sangat kompleks. Darah saya mendadak seperempat Tionghoa, nenek saya ternyata tukang bikin roti, dan dia, bersama kakek yang tidak saya kenal, mewariskan anggota keluarga yang tidak pernah saya tahu: Madre."

\section{Tulisan Tansen yang lain:}

'Saya cari di Google, kata 'Madre' itu ternyata berasal dari bahasa Spanyol, artinya 'ibu'. Madre, sang Adonan Biang, lahir sebelum ibu kandung saya. Dan, dia bahkan sanggup hidup lebih panjang dari penciptanya. Mengerikan." (Madre, hal. 20)

"Kamu orang pertama setelah Lakshmi yang bisa langsung membuat roti dari Madre tanpa gagal. Semua pekerja di sini harus mencoba berkali-kali baru berhaisl. Madrea sudah memilihmu. Sayangnya kamu ndak paham." (Madre, hal. 35) Tulisan Tansen:

"Saya meninggalkan Bali. Menetap di kota yang paling saya hindari. Bekerja rutin di suatu tempat yang sama setiap hari. Ternyata sampai hari ini saya masih waras. Saya rindu pantai. Tapi, pantai tidak perlu jadi rumah saya. Rumah adalah tempat dimana saya dibutuhkan. Dan, Madre lebih butuh saya daripada pantai mana pun di dunia. Berfamili dengan adonan roti ternyata membuat saya menemukan keluarga baru. Keluarga ini bernama "Tansen de Bakker' yang artinya Tansen di Pembuat Roti. ya. Sekarang nama saya bukan nama satu orang, melainkan enam." (Madre, hal. 78)

Madre yang mengawali kedekatan Tansen dan Mei, dengan segala romantisme 
yang terkesan tidak di sengaja dan sehingga berbuah ketertarikan Tansen yang kuat kepada Mei, seperti dalam kutipan berikut :

"Dan sekejap, ia muncul di depanku. Cantik dan menyilaukan seperti biasa. Dan hanya Tuhan yang tahu bagaimana ia bisa punya waktu untuk berdandan sebegitu heboh tiap harinya." (halaman 72).

Madre, adonan roti sederhana yang terbentuk dari fungi-lah yang menjadi titik penentu pertemuan dan menyatunya Tansen dan Mei.

"Prediksi Mei terbukti benar. Sejarah Madre yang dibuat dari tangan Lakshmi tahun 1941 menjadi buah bibir baru. Mei menjual tur untuk melihat Madre dan bagaiman adonan biang dipakai untuk menghasilkan roti dengan cita rasa klasik. Mei juga menciptakan kelas privat membuat roti dengan "menjual" trio artisan legendaris, HadiJoko-Dedeh. Atas inisiatifku, kami memiliki website, akun Facebook, Twitter, dan aneka alat promosi elektronik lain yang mungkin sampai kapan pun tidak akan sepenuhnya dipahami oleh Pak Hadi. Yang ia tahu, kami berhasil membangunkan tempat ini dari mati surinya. Kami berhasil meneruskan hidup Madre sebagaimana mestinya." (Madre, hal. 77)

"Mei tertawa lepas sampai kepalanya mendongak. Bibir itu merekah, menunjukkan deretan giginya yang putih dan indah. Pemandangan yang sangat kusukai. Itulah tawa seorang peri. Peri kami. Periku." (Madre, hal 80)
Bagi karyawan Tan de Bakker, madre bukan sekedar biang roti. Ia adalah sesuatu yang berarti dan menjadi para karyawan tetap mempertahankan toko roti tua Tan de Bakker.

"Ketika tahu rata-rata masa pengabdian kelima pegawai toko Roti Tan ini, kepada Pak Joko aku lontarkan satu pertanyaan yang mengganjal, "Bapak nggak bosan kerja di satu tempat yang sama selama itu? Pak Joko malah menatapku bingung, seakan tak mengerti kenapa hal itu dipertanyakan, "Ndak, ndak bosan. Namanya pekerjaan, yah, jalankan saja. Lagian kami juga sudah seperti keluarga di sini." Ia tertawa ringan.

"Sudah banyak suka duka selama kerja di sini. Terus terang Ibu sedih sekali Madre dilepas," kata Bu Sum kepadaku, "tapi kami ingin melepas Madre dengan bahagia. Moga-moga Madre juga senang di tempat barunya, ya."

"Kamu betul. Bagi kami, Madre itu seperti keluarga sendiri," ujarnya pelan. "Madre bukan adonan biasa. Dia hidup." Pak Hadi lalu mengambil cangkir kopiku, "Ini saya panasken lagi. Nanti saya ajarken cara ngurus Madre." (Madre, hal 13).

"Toko sudah ndak ada untung, cuma cukupan buat gaji pegawai, tapi Tan bertahan terus. Katanya, Madre jangan dibikin nganggur." (Madre, hal. 7).

"Kulkas besar itu ternyata didedikasikan untuk menyimpan satu benda saja: stoples kaca berukuran besar. Isinya adonan putih keruh. "Ini Madre." Pak Hadi berkata. Sejenak aku berharap adonan yang dipanggil Madre itu akan berubah jadi bidadari cantik atau minimal menyapa "selamat pagi". Namun, 
ia tetap diam membeku sebagaimana harusnya benda mati." (Madre, hal. 9)

"Bagi keluarga Tan de Bakker, toko itu hanya tidur. Selama Madre masih hidup dan selama keturunan Lakhsmi masih ada di luar sana, Tan de Bakker tidak pernah mati." (Madre, hal. 53)

Madre adalah asal dari semua roti yang di jual oleh Tan de Bakker. Dari Madre-lah berkembang semua jenis roti yang di jual oleh Tan de Bakker. Roti-roti yang bukan saja melambangkan hidup adonan biang itu sendiri, melainkan juga menjadi simbol penghidupan semua karyawan yang terlibat di Tan de Bakker.

"Sebagai adonan biang, sebagian Madre selalu dipakai untuk mengmbangkan roti. Sementara sisa Madre berisitirahat dalam lemari pendingin, kumpulan Saccharomyses exiguus dan Lactobacillus yang disumbangkannya tadilah yang meronggakan, mewangikan, dan merenyahkan semua roti Tan de Bakker.” (Madre, hal. 15)

"Secara rutin, kultur hidup yang ada dalam Madre diberi "makan" lagi dengan tepung dan air baru hingga ia terus berkembang biak menjadi ibu bagi roti-roti berikutnya." (Madre, hal. 15)

"Kami ndak pernah pakai ragi instan," demikian Pak Hadi bertutur tadi siang. "Setiap roti yang dibuat Tan de Bakker, dari roti pertama sampai roti terakhir yang kami jual, Madre ini biangnya." (Madre, hal. 15)

"Akan tetapi, Pak Hadi tidak tampak tersinggung. Wajahnya malah semakin iba. "Kamu betul. Bagi kami, Madre itu seperti keluarga sendiri," ujarnya pelan. "Madre bukan adonan biasa. Dia hidup."

Madre menjadi simbol pemersatu dan perekat segala jenis etnis dan ras yang ada di Tan de Bakker, bahkan yang berhasil menyatukan kakek dan neneknya Tansen yang juga berbeda ras.

"Tan bertemu dengan nenekmu, Lakshmi, waktu mereka masih muda. Mereka sama-sama bekerja di sebuah toko roti. "Kata Tan, roti buatan Lakshmi pasti rasanya beda dengan pegawai lain. Padahal, adonan yang diuleninya sama." Demikian bagian awal yang dikisahkan Pak Hadi.

Melihat talenta Lakshmi, Tan mengajaknya kerja sama. Mereka keluar dari toko roti tempat mereka bekerja dan mulai berjualan sendiri. Awalnya kecilkecilan, sampai akhirnya Tan bisa punya toko. Kedekatan mereka berangsur berubah bentuk, dari sekedar sahabat sampai keduanya saling jatuh cinta. Pak hadi geleng-geleng, "Ya, ndak mungkin. Zaman itu, India kawin sama Tionghoa. Ya, susah. Tapi, mereka ndak peduli. Nenekmu diusir keluarganya. Tan juga sama. Malangnya lagi, nenekmu ndak panjang umur. Ndak lama setelah Kartika lahir, Lakshmi meninggal. Tan sempat kacau balau. Dulu sudah hampir bangkrut dia, tapi akhirnya ditolong keluarganya. Setelah Lakshmi ndak ada, Tan dan orang tuanya akur lagi. Ya, jadilah toko roti ini." (Madre, hal. 11) 
"Pak Hadi memperkenalkan mereka satu-satu. Nenek yang kali pertama menyapaku adalah $\mathrm{Bu}$ Cory, pegawai tertua yang telah bekerja untuk Pak Tan selama lima puluh tahun lebih. $\mathrm{Bu}$ Sum, yang berperawakan gemuk pendek dengan rambut disanggul, masa pengabdiannya hanya beda beberapa tahun saja dengan Bu Cory. Keduanya dulu bekerja di bagian depan, bertugas melayani pembeli dan menjadi kasir. Nenek berikutnya, yang merupakan pegawai ter-"muda" adalah $\mathrm{Bu}$ Dedeh, masa pengabdiannya "baru" tiga puluh tahunan, saat Tan de Bakker sudah berubah menjadi Toko Roti Tan. Bu Dedeh berangkat langsung dari Tasikmalaya untuk bekerja di toko itu. Dan, ternyata $\mathrm{Bu}$ Dedeh masih mengenal keluarga Aki di Tasikmalaya. Satu-satunya eks pegawai pria selain Pak Hadi adalah Pak Joko, yang berkopiah, bersuara lembut, dab cenderung pendiam. Tubuhnya tinggi dengan bahu condong ke dalam seolah ia senantiasa memberi tanda "permisi". Pak Joko mengabdi empat puluh tahunan di sini, bertugas bersama Pak Hadi dan $\mathrm{Bu}$ Dedeh di dapur sebagai pembuat roti." (Madre, hal. 37)

"Yang jelas bagiku hanyalah: aku atau uang seratus juta tak pantas menggusur Madre keluar dari sini. Tempat tua ini adalah rumahnya. Orang-orang tua ini adalah keluarga sejatinya." (Madre. Hal. 43)

Dari pemaparan yang diambil dari kutipan cerpen Madre, dapat dilihat bahwa sekalipun Madre hanyalah sebuah adonan roti sederhana, namun kekuatannya mampu menyatukan berbagai pribadi yang tadinya tidak saling kenal dan menjalani kehidupan mereka masing-masing. Mimpi dan harapan tiap orang yang terlibat dan bersentuhan dengan Madre seakan semakin diteguhkan dan dibangkitkan oleh kehadiran dan keberadaan Madre. Tansen, Pak Hadi, Mei, Bu Cory, Bu Dedeh, Pak Joko sama sekali tidak memiliki hubungan darah, namun mereka semua terikat kepada Madre dengan cara yang indah, menjadi keluarga yang berharmoni bersama mewujudkan mimpi masing-masing. Atas dasar itu semua, Madre layak disebut ibu, sumber kehidupan yang menerangi semua yang setia dan menyayanginya.

\section{PENUTUP}

Berbagai cara dilakukan penulis untuk mengungkapkan maksud dan tujuan mereka dalam karya sastra yang dilahirkan. Berdasarkan analisis yang telah dilakukan, cerpen Madre karya Dewi Lestari berhasil menghadirkan keterhubungan berbagai manusia yang datang dari latar belakang berbeda-beda yang di bagian akhir dikaitkan dengan indah oleh kehadiran sebuah adonan roti sederhana.

\section{DAFTAR PUSTAKA}

Berger, Arthur Asa. 2005. Tanda-tanda dalam Kebudayaan Kontemporer: Suatu Pengantar Semiotika. Yogyakarta: Tiara Wacana.

Burhan Nurgiyantoro. (1995). Teori Pengkajian Fiksi. Yogyakarta: Gadjah Mada University Press.

Jatmiko, Sumarwati dan Raheni Suhita. 2012. Konflik Batin Tokoh-tokoh dala Kumpulan Cerita Madre Karya Dewi Lestari. 
Program Studi Pendidikan Bahasa Indonesia, Fakultas Keguruan dan Ilmu Pendidikan, Universitas Sebelas Maret Malang.

Kurniawan. 2001. Semiologi Roland Barthes. Magelang: Yayasan Indonesia Tera.

Lestari, Dewi. 2015. Madre. Jakarta: Bentang Pustaka.

Luxemburg, dkk... 1984. Pengantar Ilmu Sastra. Terjemahan Bahasa Indonesia oleh Dick Hartoko. Jakarta. Gramedia.

Nurgiyantoro, Burhan. 2009. Penilaian Dalam Pengajaran Bahasa Dan Sastra. Yogykarta: BPFE.

Pradopo, Rachmat Djoko. 2002. Kritik Sastra Modern. Yogyakarta: Gama Media.

Ratna, Nyoman Kutha. 2004. Teori, Metode, Dan Teknik Penelitian Sastra (Dari Strukturalisme Hingga Postrukturalisme, Perspektif Wacana Naratif). Yogyakarta: Pustaka Pelajar.

Santosa, Puji. 1993. Ancangan Semiotika dan Pengkajian Susastra. Bandung. Angkasa.

Saida, Akmaliatus. 2012. Gaya Bahasa dalam Cerita Madre Karya Dewi Lestari. Skripsi. Jurusan Sastra Indonesia, Fakultas Sastra, Universitas Negeri Malang.

Semi, M. Atar. 1993. Metode Penelitian Sastra. Bandung. Angkasa.

Siswantoro. 2005. Metode Penelitian Sastra: Analisis Psikologis. Surakarta. UMS.

Sobur, Alex. (2009). Semiotika Komunikasi. Bandung: PT Remaja Rosdakarya.

Tarigan, Henry Guntur. 1991. Prinsip-Prinsip Dasar Sastra. Bandung: Angkasa Bandung.

Tinarbuko, Sumbo. 2012. Semiotika Komunikasi Visual. Yogyakarta. Jala Sutra.

Wellek, Renne Dan Austin Warren. 1990. Teori Kesusastraan (Diterjemahkan Oleh Melani Budianta). Jakarta: Pustaka Jaya.
Zaimar, O.K.S. 2008. Semiotik dan Penerapannya dalam Karya Sastra. Jakarta: Pusat Bahasa Departemen Pendidikan Nasional. 